\title{
Myoelectrical changes in the uterus of the sheep around parturition
}

\author{
C. R. Krishnamurti, D. D. Kitts, W. D. Kitts and J. G. Tompkins \\ Department of Animal Science, University of British Columbia, Vancouver, \\ British Columbia V6T 2A2, Canada
}

\begin{abstract}
Summary. Myoelectrical activity in the uterus of late-pregnant sheep was recorded by the chronic implantation of bipolar electrodes in the myometrium. Three distinct patterns of electrical activity were recognizable: irregular trains of action potentials $(>120 \mathrm{sec})$, long spike bursts $(7-120 \mathrm{sec})$, or short spike bursts $(<7 \mathrm{sec})$ each exhibiting high $(>100 \mu \mathrm{V})$ or low $(50-100 \mu \mathrm{V})$ amplitude. The duration of spike activity was expressed as the myoelectrical index (MI), i.e. the fraction of the hour during which a given category of activity is exhibited.

The increase in the overall MI which represents daily average values regardless of the class of amplitude from $72 \mathrm{~h}$ pre partum up to parturition was significantly $(P<0.05)$ more pronounced in the uterine horn than in the body of the uterus. During the last 6-7 days of gestation high-amplitude irregular trains and long spike bursts were significantly $(P<0.05)$ more frequent than these activity patterns with low amplitude. Regardless of the amplitude, the incidence of irregular trains began to decline rapidly $48 \mathrm{~h}$ pre partum with an abrupt cessation following parturition. The frequency of long spike bursts increased $72 \mathrm{~h}$ pre partum to reach a maximum which coincided with parturition.
\end{abstract}

\section{Introduction}

Studies on the electrical properties of the uterine smooth muscle and the development of techniques for the continuous recording of uterine myoelectrical activity in vivo have contributed much to our understanding of the physiological basis of myometrial function. Changes in uterine myoelectrical activity during different phases of the oestrous cycle have been reported for the rat (Ishikawa \& Fuchs, 1978), cow (Ruckebusch \& Bayard, 1975), sheep (Naaktgeboren et al., 1973; Rousseau \& Prud'homme, 1974; Prud'homme, 1976; Ruckebusch \& Bueno, 1976) and mare (Kao, 1977; Taverne et al., 1979b). The electromyographic activity of the uterus during pregnancy and parturition when the uterus is subjected to the actions of several hormones has been studied by Bosc \& Fevre (1974) and Naaktgeboren, Kroon \& Schoof (1975). Wolfs \& van Leeuwen (1979) and Sakaguchi \& Nakajima (1973) have characterized the electromyographic activity of the uterus during human labour and Bosc, du Mesnil du Buisson \& Locatelli (1974), Bosc, Locatelli, Nicolle \& du Mesnil du Buisson (1976) and Taverne, Naaktgeboren \& van der Weyden (1979a) have studied the uterine changes in pigs at the time of parturition. The pattern of myoelectrical changes in the sheep uterus in the periparturient period was described by Prud'homme \& Bosc (1977) and Krishnamurti, Kitts \& Tompkins (1979). In the present study the characteristics of these myoelectrical changes were investigated in quantitative terms. 


\section{Materials and Methods}

Animals. Thirteen Dorset or Dorset/Suffolk crossbred ewes $(50-75 \mathrm{~kg})$ of known gestational age were used. They were kept in individual pens and efforts were made to minimize excitement due to external factors. The ewes were fed dehydrated lucerne cubes at the rate of $1300 \mathrm{~g} /$ day. Water was made available ad libitum.

Surgery. At 120 days of gestation the ewes were anaesthetized using $1.5 \%$ halothane (Fluothane: Ayerst) in oxygen and a mid-line laparotomy was performed as described by Kitts, Krishnamurti \& Kitts (1979). The pregnant horn was identified and fine bipolar electrodes were passed through the serosa and implanted in the myometrium in the body (corpus uteri) near the bifurcation and at the uterotubal junction in the horn. Initially, platinum electrodes (Grass E.2, length $2 \mathrm{~cm}$; diameter $250 \mu \mathrm{m}$; inter-tip distance $3 \mathrm{~mm}$ ) were used; in later experiments bipolar electrodes were constructed from stainless-steel dental broches (Nervnadelin; length $1 \mathrm{~cm}$; diameter $250 \mu \mathrm{m}$ ) with an inter-tip distance of $3 \mathrm{~cm}$. They were found to be economical and equally effective. The electrode leads were passed subcutaneously on the side of the animal and exteriorized approximately $10 \mathrm{~cm}$ below the transverse processes of the lumbar vertebrae. To monitor intrauterine pressure simultaneously with myoelectrical activity, open-tip catheters were placed in the amniotic cavity and connected to a Statham P25 pressure transducer. The catheter was flushed daily with saline $(9 \mathrm{~g} \mathrm{NaCl} / \mathrm{l})$ to prevent blockage. The abdominal incision was closed and experiments were begun after at least 5 days since surgery. The insulated extension leads from the electrodes were connected directly to a Grass Polygraph multichannel recorder (Model 7P; 7P3 amplifier) in which the amplifier had a high frequency cut off at $35 \mathrm{~Hz}$. Each channel was calibrated to give a deflection of $200 \mu \mathrm{V} / \mathrm{cm}$ peak to peak. Recordings were made daily for $8 \mathrm{~h}$ at a chart speed of $25 \mathrm{~mm} / \mathrm{min}$. When parturition was expected, recordings were obtained on a continuous basis until 5 days post partum. The average gestation length of the ewes used in this study was $140.4 \pm 0.92$ (s.e.m.) days. Only one ewe carried twins and the results are included in the data.

Analysis of electromyographic data. Based on the maximum amplitude, the spike discharges were classified as high $(>100 \mu \mathrm{V})$ or low $(50-100 \mu \mathrm{V})$. Spiking activity was further subdivided, on the basis of duration, into three classes: irregular trains of action potentials refer to a diffuse pattern of spike activity occurring continuously for more than $2 \mathrm{~min}$, long spike bursts displayed a rhythmic pattern of activity and lasted 7-120 sec, while short spike bursts occurred for periods $<7 \mathrm{sec}$. Interruption of electrical activity for a minimum of $5 \mathrm{sec}$ was used as the criterion to consider successive spike discharges as separate events. The classification of electrical activity according to amplitude and duration is based on experiments with extracellular electrodes which show that synchronous individual spikes give rise to high amplitude signals of short duration, whereas asynchronous spikes result in low amplitude bursts of long duration (Kao, 1977).

The amplitude, frequency and length $(\mathrm{mm})$ of continuous myoelectrical activity in each hour were tabulated by hand using a calibrated Perspex scale. A computer program was developed to facilitate transformation of the data on lengths of activity $(\mathrm{mm})$ recorded on chart paper to duration (sec) and classification into different categories. The actual duration of different categories of spike activity in each hour was totalled separately and expressed as the myoelectrical index (MI), which is defined as the percentage of each hour during which a given class of activity was exhibited:

$$
=\frac{\sum_{\mathbf{i}} \mathrm{di}}{3600} \times 100,
$$

where $\sum_{i}^{N} d i=$ duration $(\mathrm{sec})$ of each class of activity in $1 \mathrm{~h}$, di $=\left(\mathrm{d}_{1}+\mathrm{d}_{2}+\mathrm{d}_{3} \ldots \mathrm{di}\right)=$ duration of each event and $\mathbf{N}=$ number of events in the appropriate class. 
Statistical analysis of the myoelectrical index of different classes of spike activity pre and post partum was by Student's $t$ test.

\section{Results}

Typical patterns of spike activities (irregular trains, long and short bursts) and intrauterine pressure changes observed in this study are shown in Text-fig. 1. The electrical activity always preceded the intrauterine pressure by $10-12 \mathrm{sec}$ and coincided with the rising phase of the intrauterine pressure contraction. By increasing the chart speed it was possible to detect $25 \pm 4$ individual spikes in each long burst at parturition. An example of the calculation used in the computation of the myoelectrical index is given using the activity shown in Text-fig. 2 .

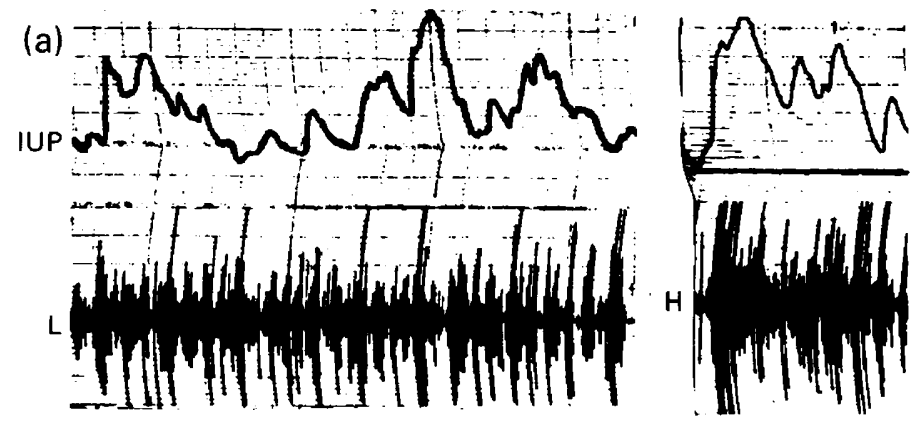

(b)
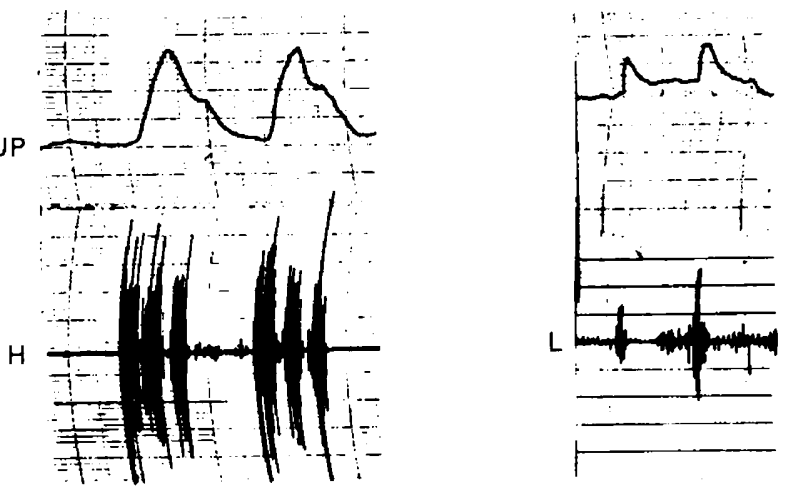

(c)

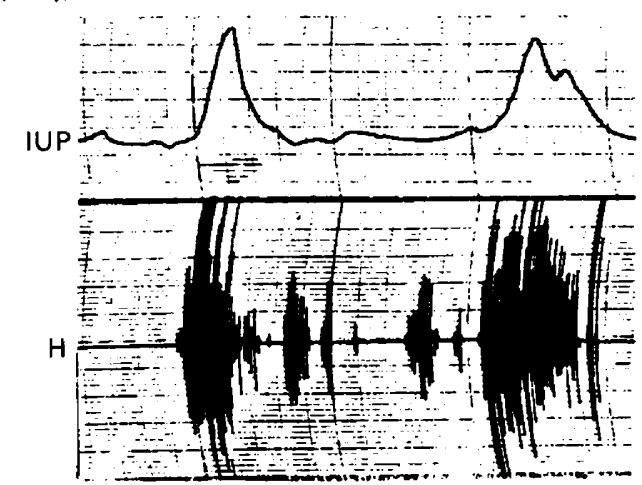

Text-fig. 1. Patterns of myoelectrical activity and corresponding intrauterine pressure (IUP) changes in the sheep uterus around parturition: (a) irregular trains of action potentials showing low (L) or high (H) amplitude; (b) short spike bursts showing high (H) or low (L) amplitude; and (c) long spike bursts of high amplitude. 

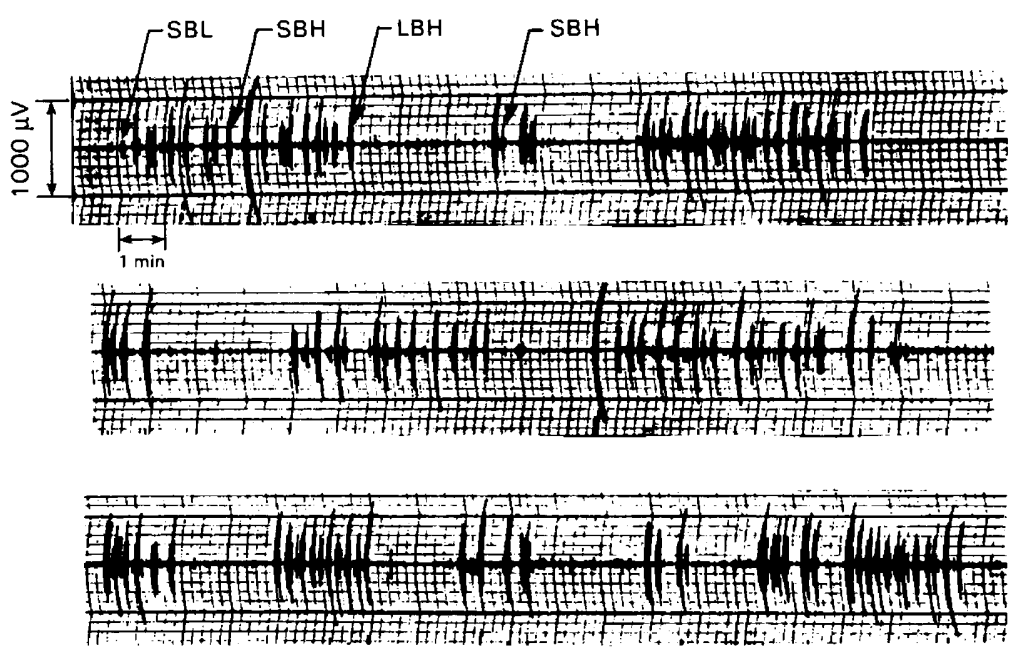

Text-fig. 2. Electrical activity in the uterine horn of a sheep during the 7 th hour pre partum. Recordings are continuous from left to right. During the first $12 \mathrm{~min}(720 \mathrm{sec})$ the overall duration of spike activity regardless of class of amplitude was $71.4 \mathrm{sec}$. This consisted of 1 short burst of low amplitude (SBL) with a duration of $1.8 \mathrm{sec}$, two short bursts of high amplitude (SBH) with a duration of $4.6 \mathrm{sec}$, and 18 long bursts of high amplitude (LBH) with a duration of $65 \mathrm{sec}$. In this example, the myoelectrical index (i.e. \% activity/h) for the short bursts of low amplitude was $(1.8 / 720) \times 100=0.25$; for the short bursts of high amplitude was $(4.6 / 720) \times$ $100=0 \cdot 64$; for the long bursts of high amplitude was $(65 / 720) \times 100=9 \cdot 03$. The overall index was $(71 \cdot 4 / 720) \times 100=9.92$.

The overall myoelectrical index, which represented the daily average values of uterine electrical activity regardless of the class or amplitude (Text-fig. 3) indicated that the myoelectrical activity in the body as well as the horn began to increase approximately $72 \mathrm{~h}$ before parturition. After reaching a maximum at parturition there was an abrupt decrease in the index for periods up to $48 \mathrm{~h}$, after which the electrical activity was low and sporadic. The increase in the myoelectrical index of the horn as determined from the slope (8.86) from $72 \mathrm{~h}$ pre partum up to parturition was significantly $(P<0.05)$ more pronounced than that $(2.85)$ in the body of the uterus, suggesting that electrical activity first appeared at the uterotubal junction. In the period immediately preceding and following parturition, the myoelectrical index in the body of the uterus increased from values of $25-30$ at $12 \mathrm{~h}$ pre partum to $70-80$ at the time of parturition (Text-fig. 4).

The changes in the amplitude of electrical activity of the uterine body are given in Table 1 . Until 10 days before parturition, the electrical activity was dominated by irregular trains of action potentials of variable amplitude. The index for high-amplitude long spike bursts was significantly $(P<0.05)$ lower than that for low amplitude long spike bursts at this time. During the last 6-7 days of gestation the indexes for high-amplitude irregular trains of action potentials and long spike bursts were significantly $(P<0.05)$ greater than those for the equivalent patterns of low amplitude (Table 1). The difference remained until parturition when there was a precipitous drop in the index for high-amplitude trains and spike bursts to the same level as the low-amplitude ones.

The myoelectrical index for the 3 class of spike activities (high plus low amplitudes) is shown in Text-fig. 5. During the last week of gestation the irregular trains of action potential in the body were more predominant than long or short spike bursts. Approximately $48 \mathrm{~h}$ before parturition the irregular trains began to decline rapidly and there was an abrupt cessation of trains immediately after parturition. The index for long spike bursts increased $72 \mathrm{~h}$ pre partum and the increase continued even after parturition. The index for short spike bursts was very low in comparison with that for trains of long spike bursts. There was a slight increase in short spike 


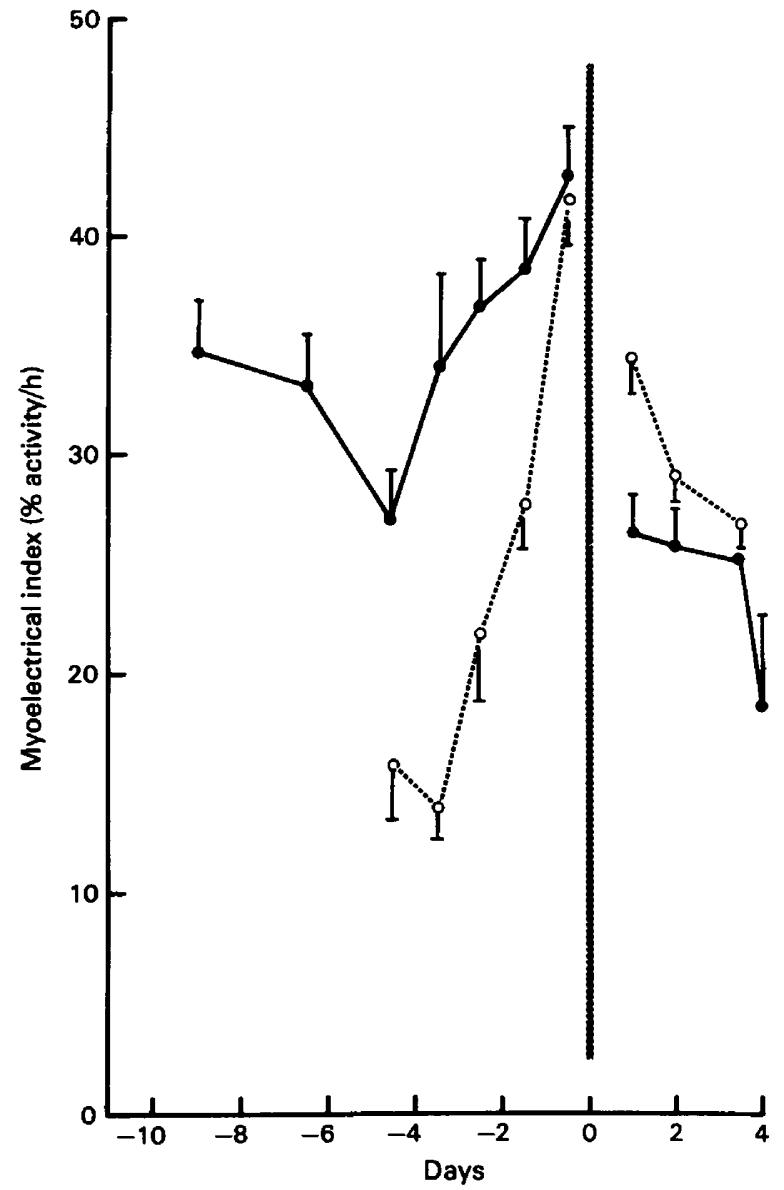

Text-fig. 3. Daily changes in overall myoelectrical activity, regardless of class or amplitude, of the sheep uterine horn $(O)$ and uterine body $(\mathbf{O})$. Parturition = Day 0.

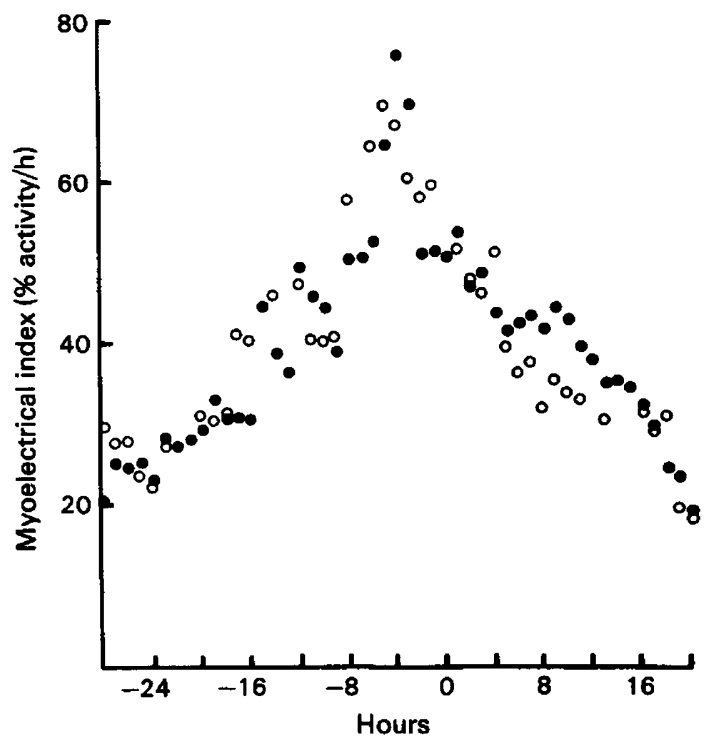

Text-fig. 4. Hourly changes in overall myoelectrical activity in the uterine body of 2 ewes $(0,0)$ in the period immediately preceding and following parturition $(0 \mathrm{~h})$. 
Table 1. Changes in the amplitude and class of electrical activity in the body of the sheep uterus around parturition (Day 0)

\begin{tabular}{|c|c|c|c|c|c|c|c|}
\hline \multirow[b]{3}{*}{$\begin{array}{l}\text { Period } \\
\text { (days) }\end{array}$} & \multirow{3}{*}{$\begin{array}{l}\text { No. of } \\
\text { hours } \\
\text { of } \\
\text { recording }\end{array}$} & \multicolumn{6}{|c|}{ Myoelectrical index (\% activity $/ \mathrm{h}$ ) } \\
\hline & & \multicolumn{3}{|c|}{$\begin{array}{l}\text { Low amplitude } \\
(50-100 \mu \mathrm{V})\end{array}$} & \multicolumn{3}{|c|}{$\begin{array}{l}\text { High amplitude } \\
\qquad>100 \mu \mathrm{V})\end{array}$} \\
\hline & & $\begin{array}{l}\text { Short } \\
\text { bursts }\end{array}$ & $\begin{array}{l}\text { Long } \\
\text { bursts }\end{array}$ & Trains & $\begin{array}{l}\text { Short } \\
\text { bursts }\end{array}$ & $\begin{array}{l}\text { Long } \\
\text { bursts }\end{array}$ & Trains \\
\hline-10 to -8 & 88 & $\begin{array}{l}0.17 \pm \\
0.05\end{array}$ & $\begin{array}{l}3.65 \pm \\
0.37\end{array}$ & $\begin{array}{c}14.78 \pm \\
1.81\end{array}$ & $\begin{array}{l}0.19 \pm \\
0.05\end{array}$ & $\begin{array}{c}* 1.93 \pm \\
0.28\end{array}$ & $\begin{array}{c}16.67 \pm \\
1.66\end{array}$ \\
\hline-7 to -6 & 70 & $\begin{array}{l}0.30 \pm \\
0.05\end{array}$ & $\begin{array}{l}2 \cdot 16 \pm \\
0.81\end{array}$ & $\begin{array}{l}6.71 \pm \\
1.22\end{array}$ & $\begin{array}{l}0.34 \pm \\
0.05\end{array}$ & $\begin{array}{c}* 3.55 \pm \\
0.43\end{array}$ & $\begin{array}{c}* 21.39 \pm \\
2.40\end{array}$ \\
\hline-5 to -4 & 111 & $\begin{array}{l}0.24 \pm \\
0.04\end{array}$ & $\begin{array}{l}2.37 \pm \\
0.29\end{array}$ & $\begin{array}{l}1.91 \pm \\
0.45\end{array}$ & $\begin{array}{l}* 0.37 \pm \\
0.05\end{array}$ & $\begin{array}{c}* 4.35 \pm \\
0.41\end{array}$ & $\begin{array}{c}18.04 \pm \\
2.12\end{array}$ \\
\hline-4 to -3 & 35 & $\begin{array}{l}0.31 \pm \\
0.06\end{array}$ & $\begin{array}{l}4.64 \pm \\
1.12\end{array}$ & $\begin{array}{l}4.09 \pm \\
1.00\end{array}$ & $\begin{array}{l}{ }^{* 0} 0.29 \pm \\
0.08\end{array}$ & $\begin{array}{c}* 5.47 \pm \\
0.74\end{array}$ & $\begin{array}{c}* 19.55 \pm \\
4.81\end{array}$ \\
\hline-3 to -2 & 35 & $\begin{array}{l}0.32 \pm \\
0.09\end{array}$ & $\begin{array}{l}3.59 \pm \\
0.49\end{array}$ & $\begin{array}{l}3.29 \pm \\
0.86\end{array}$ & $\begin{array}{l}0.35 \pm \\
0.49\end{array}$ & $\begin{array}{c}* 9.11 \pm \\
6.06\end{array}$ & $\begin{array}{c}* 20.27 \pm \\
2.21\end{array}$ \\
\hline-2 to -1 & 64 & $\begin{array}{l}0.24 \pm \\
0.16\end{array}$ & $\begin{array}{l}6.27 \pm \\
1.24\end{array}$ & $\begin{array}{l}4.07 \pm \\
0.91\end{array}$ & $\begin{array}{l}0.29 \pm \\
0.05\end{array}$ & $\begin{array}{c}* 12.61 \pm \\
1.69\end{array}$ & $\begin{array}{c}* 15.29 \pm \\
1.63\end{array}$ \\
\hline-1 to 0 & 58 & $\begin{array}{l}0.40 \pm \\
0.08\end{array}$ & $\begin{array}{l}9.62 \pm \\
0.91\end{array}$ & $\begin{array}{l}0.69 \pm \\
0.27\end{array}$ & $\begin{array}{c}* 0.73 \pm \\
0.13\end{array}$ & $\begin{array}{c}* 24.64 \pm \\
1.65\end{array}$ & $\begin{array}{r}* 7.17 \pm \\
1.07\end{array}$ \\
\hline 0 to 1 & 53 & $\begin{array}{l}0.89 \pm \\
0.11\end{array}$ & $\begin{array}{c}14.04 \pm \\
2.12\end{array}$ & $\begin{array}{l}0.24 \pm \\
0.19\end{array}$ & $\begin{array}{l}0.43 \pm \\
0.11\end{array}$ & $\begin{array}{c}10.20 \pm \\
1.98\end{array}$ & $\begin{array}{l}0.71 \pm \\
0.30\end{array}$ \\
\hline 1 to 2 & 29 & $\begin{array}{l}1.29 \pm \\
0.19\end{array}$ & $\begin{array}{c}15 \cdot 23 \pm \\
2 \cdot 27\end{array}$ & $\begin{array}{l}1 \cdot 19 \pm \\
1 \cdot 19\end{array}$ & $\begin{array}{l}0.63 \pm \\
0.22\end{array}$ & $\begin{array}{l}7.66 \pm \\
1.96\end{array}$ & - \\
\hline 2 to 3 & 5 & $\begin{array}{l}0.70 \pm \\
0.11\end{array}$ & $\begin{array}{c}15.06 \pm \\
1.69\end{array}$ & $\begin{array}{l}6.83 \pm \\
6.83\end{array}$ & $\begin{array}{l}0.054 \pm \\
0.054\end{array}$ & $\begin{array}{l}2.76 \pm \\
2.76\end{array}$ & - \\
\hline 3 to 4 & 7 & $\begin{array}{l}0.97 \pm \\
0.20\end{array}$ & $\begin{array}{c}18.88 \pm \\
3.99\end{array}$ & $\begin{array}{l}1.44 \pm \\
1.44\end{array}$ & $\begin{array}{l}0.44 \pm \\
0.142\end{array}$ & $\begin{array}{l}2.71 \pm \\
1.31\end{array}$ & $\begin{array}{l}1.50 \pm \\
1.50\end{array}$ \\
\hline
\end{tabular}

Values are mean \pm s.e.m.

* Significantly different from corresponding low-amplitude values: $P<0.05$.
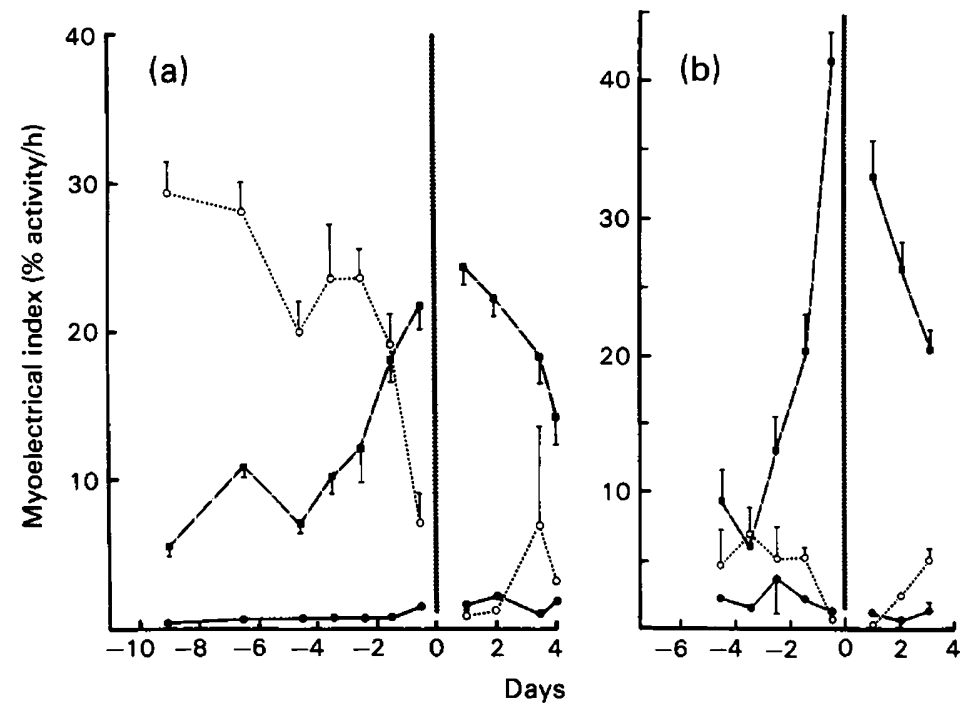

Text-fig. 5. Spike activity in the body (a) and horn (b) of the sheep uterus around the time of parturition (Day 0 ). $\mathbf{m}$, Long spike bursts; $O$, irregular trains of action potential; $\boldsymbol{O}$, short spike bursts. Values are mean \pm s.e.m. 
bursts after parturition (Text-fig. 5a). The myoelectrical index for the 3 classes of electrical activities in the uterine horn was similar to that in the body except that the incidence of irregular trains of action potentials was lower than that of long spike bursts before parturition (Text-fig. $5 b$ ). The occurrence of long spike bursts reached a maximum which coincided with parturition.

\section{Discussion}

The occurrence of electrical spike activity a few seconds before the increase in intrauterine pressure and coincidence with the rising phase of the pressure contraction confirm the observations of Wolfs \& van Leeuwen (1979) in relation to human labour.

Although intrauterine pressure changes are usually expressed in terms of active pressure area and activity units (e.g. Montevideo Units) the inadequacies of existing methods have been emphasized by Braaksma, Veth, Eskes \& Stolte (1972) and Finn \& Porter (1975). The limitations of motility indices when both the amplitude and frequency show distinct changes have also been recognized by those studying the electrical activity of the gastrointestinal tract (Schuurkes, van der Schee, Grashuis \& Charbon, 1975). Under these conditions a single motility index value derived from amplitude and frequency conceals the different responses of each characteristic. For this reason duration, as measured by myoelectrical index, and amplitude were treated separately in the present study to follow the changes with gestation.

The temporal relationship of the three classes of uterine electrical activity with gestational age and parturition observed in this study gives an indication of their physiological significance. The irregular trains of potential fluctuations noticeable in late gestation represent electrical activity in isolated groups of myometrial cells and may give rise to episodes of weak and localized contractions, depending on their amplitude. As parturition approaches they decrease in frequency and are replaced by bursts of spike activity which begin to increase approximately $72 \mathrm{~h}$ before parturition.

The long bursts of spike activity with amplitudes higher than $100 \mu \mathrm{V}$ represent co-ordinated and rhythmic activity of several groups of cells or contractile units. The sudden increase in their duration and amplitude $48 \mathrm{~h}$ pre partum marks the onset of physiological preparations for parturition and corresponds to the increase in plasma oestrogens and prostaglandin $\mathrm{F}$ and the decrease in the progesterone concentration in the ewe and the increase in the fetal corticosteroid values (Rawlings \& Ward, 1978). At about $12 \mathrm{~h}$ pre partum the total myoelectrical activity, particularly long spike bursts (Text-figs 4 and 5 a), increases abruptly and corresponds to the onset of uterine contractions reported by Hindson \& Ward (1973) during this period. The asynchronous electrical behaviour of the myometrial cells up to $24 \mathrm{~h}$ pre partum and the sudden change to a phase of co-ordinated activity thereafter, culminating in parturition, support the concept (van Leeuwen, Boeles \& Wolfs, 1979) that the myometrium behaves as a multiple unit in late gestation and as a single unit of electrical syncytium during parturition. The anatomical basis of this property has been ascribed to the rapid appearance just before parturition of nexuses (gap junctions) which facilitate intercellular electrical coupling (Garfield, Rabideau, Challis \& Daniel, 1979). The very steep increase in electrical activity, especially long spike bursts, in the uterine horn (Text-figs 3 and $5 \mathrm{~b}$ ) as compared to the body at $72 \mathrm{~h}$ pre partum suggests that electrical activity is propagated in the tubocervical direction, thus facilitating the expulsion of the fetus. This is consistent with the findings of Taverne et al. (1979a) who reported that phases of propagated activity first appeared at the two ends of the horn in sows during parturition. It has not been possible to estimate the propagation velocity in the present study because several electrodes implanted successively along the uterine axis are required.

Although it has not been possible to identify a circumscribed pacemaker in the uterus (Wolfs \& van Leeuwen, 1979) and the myometrial cells are potentially capable of autonomously 
generating impulses (Kao, 1977), the observation that bursts of electrical activity first appear at the uterotubal junction during parturition in the ewe suggests that there may be specialized cells in this region which are easily depolarized by intrinsic and/or extrinsic stimuli as suggested by Sakaguchi \& Nakajima (1973). A comparison of changes in the membrane potential of cells from the uterotubal junction with those from other areas of the uterus subjected to different hormonal conditions in vitro would be of interest.

One of the advantages of studying electrical activity by the chronic implantation of electrodes in the myometrium to monitor changes in uterine motility in experimental animals under different physiological conditions has been claimed to be that each animal can act as its own control (Naaktgeboren et al. 1973). However, the demonstration (Bontekoe, Blacqiuere, Naaktgeboren, Dieleman \& Willems, 1977) that myometrial activity is easily influenced by excitement and other external factors led us to combine the data from several sheep and study the temporal changes to minimize variability due to non-specific response to environmental stimuli. It is recognized that while the differences in the duration and amplitude are distinguishable, a small amount of overlapping in the different classes of activity is inherent in the manual procedure employed. However, the quantitative approach used in this study to analyse the complex electrohysterograms would be valuable for monitoring uterine activity under different physiological conditions.

Supported by the Natural Sciences and Engineering Research Council Canada and Agriculture Canada.

\section{References}

Bontekoe, E.H.M., Blacqiuere, J.F., Naaktgeboren, C., Dieleman, S.J. \& Willems, P.P.M. (1977) Influence of environmental disturbances on uterine motility during pregnancy and parturition in rabbit and sheep. Behav. Processes 2, 41-73.

Bosc, M. \& Fevre, J. (1974) Etude du mode d'action de la dexamethasone utilisée pour induire l'agnelage chez la brebis. C.r. hebd. Séanc. Acad. Sci. Paris D 278, 315-318.

Bosc, M., du Mesnil du Buisson, F. \& Locatelli, A. (1974) Mise en evidence d'un controle foetal de la parturition chez la truie. Interactions la fonction luteale. C.r. hebd. Séanc. Acad. Sci., Paris D 278, 1507-1510.

Bosc, M., Locatelli, A., Nicolle, A. \& du Mesnil du Buisson, F. (1976) Effect of inversion of one or both uterine horns on farrowing in sow. Annls Biol. anim. Biochim. Biophys. 16, 645-648.

Braaksma, J.T., Veth, A.F.L., Eskes, A.B. \& Stolte, L.A.M. (1972) Digital evaluation of uterine contraction records. In Uterine Contraction-Side Effects of Steroidal Contraceptives, pp. 9-18. Ed. J. B. Josimovich. Wiley, New York.

Finn, C.A. \& Porter, D.G. (1975) The Uterus, pp. 173-178. Elek Ltd, London.

Garfield, R.E., Rabideau, S., Challis, J.R.G. \& Daniel, E.E. (1979) Hormonal control of gap function in sheep myometrium during parturition. Biol. Reprod. 21, 999-1007.

Hindson, J.C. \& Ward, W.R. (1973) Myometrial studies in the pregnant sheep. In The Endocrinology of Pregnancy and Parturition, pp. 153-162. Ed. C. G. Pierrepoint. Alpha Omega Alpha, Cardiff.
Ishikawa, M. \& Fuchs, A. (1978) Electrical and mechanical activity of rat uterus in vivo during the estrous cycle. Am.J. Obstet. Gynec. 132,611-619.

Kao, C.Y. (1977) Electrophysiological properties of the uterine smooth muscle. In Biology of the Uterus, pp. 432-496. Ed. R. M. Wynn. Plenum Press, New York.

Kitts, D.D., Krishnamurti, C.R. \& Kitts, W.D. (1979) Post-surgical changes in blood parameters of the ovine fetus in utero. Can. J. Anim. Sci. 59, 265-271.

Krishnamurti, C.R. Kitts, D.D. \& Tompkins, J.G. (1979) Uterine myoelectrical activity in the peripartal ewe. Annls Rech. Vet. 10, 183-185.

Naaktgeboren C., van der Weyden, G.C., Klopper, P.J., Kroon, C.H., Schoof, A.G. \& Taverne, M.A.M. (1973) Electrophysiological observations of uterine motility during the oestrous cycle in sheep. J. Reprod. Fert. 35, 511-518.

Naaktgeboren, C., Kroon, C. H. \& Schoof, A.G. (1975) Uber die wehentatigkeit des kaninchens. Eine elektrophysiologische studie der uterusaktivitat und eine theorie uber die auslosung des geburts beginns. $Z$. Saugetierk. 40, 150-172.

Prud'homme, M.-J. (1976) Etude electromyographique de l'organization de la motricité uterine au cours de l'oestrus chez la brebis. Annls Biol, anim. Biochim. Biophys. 16, 821-831.

Prud'homme, M.-J. \& Bose, M.J. (1977) Motricite uterine de la brebis avant pendant et après la parturition spontanée ou après traitment par la dexamethasone. Annls Biol. anim. Biochim. Biophys. 17, 9-19.

Rawlings, N.C. \& Ward, W.R. (1978) Correlations of 
maternal and fetal endocrine events with uterine pressure changes around parturition in the ewe. $J$. Reprod. Fert. 54, 1-8.

Rousseau, J.-P. \& Prud'homme, M.-J. (1974) Etude electromyographique de la motricite de l'uterus chez la brebis. Action des hormones. Annls Biol. anim. Biochim. Biophys. 14, 67-85.

Ruckebusch, Y. \& Bayard, F. (1975) Motility of the oviduct and uterus of the cow during the oestrous cycle. J. Reprod. Fert. 43, 23-82.

Ruckebusch, Y. \& Bueno, L. (1976) An electromyographic study of the uterotubal activity in the ewe. $J$. Reprod. Fert. 47, 221-227.

Sakaguchi, M. \& Nakajima, A. (1973) Electromyogram of the human uterus in labor. J. appl. Physiol. 35, 425-426.

Schuurkes, J.J.A., van der Schee, E.J., Grashuis, J.L. \& Charbon, G.R.A. (1975) Calibration of strain gauge force transducers and quantification of gastric motility. In Gastrointestinal Motility in Health and Disease, pp. 647-654. Ed. H. L. Duthie. M.T.P Press, Lancaster.

Taverne, M.A.M., Naaktgeboren, C. \& van der Weyden, G.C. (1979a) Myometrial activity and expulsion of fetuses. Anim. Reprod. Sci. 2, 117-131.

Taverne, M.A.M., van der Weyden, G.C., Fontijne, P., Dieleman, S.J., Pashen, R.L. \& Allen, W.R. (1979b) In-vivo myometrial electrical activity in the cyclic mare. J. Reprod. Fert. 56, 521-532.

van Leeuwen, M., Boeles, J.Th.F. \& Wolfs, G.M.J. (1979) Some physiological aspects of uterine contractibility in man. In Human Parturition, pp. 41-48. Eds M. J. N. C. Keirse, A. B. M. Anderson \& J. B. Gravenhorst. Leiden University Press.

Wolfs, G.M.J. \& van Leeuwen, M. (1979) Electro myographic observations on the human uterus during labour. Acta obstet. gynec. scand., Suppl. 90, $1-61$. 